\title{
GENERAL ASPECTS REGARDING THE SITUATIONS WHEN THE RULES OF GOOD CONDUCT IN SCIENTIFIC RESEARCH CAN BECOME OFFENCES
}

\author{
Ionela Cecilia ȘULEA (BUTILĂ) \\ "Lucian Blaga" University of Sibiu, Romania \\ "Dimitrie Cantemir" University, Tîrgu Mureș, Romania \\ cecilia_bic_22@yahoo.com
}

\begin{abstract}
The purpose of the paper is to clarify the situations when deviations from the rules of good conduct in scientific research are considered to be offenses. The paper, in the first part, it is focused on the idea of offence and it definition, because it is important to define this term in order to compare deviations and offences. In the second part, the paper refers to those situations when the deviations from the rules of good conduct in scientific research can become offences according to the Criminal Code. In addition, in the paper are analyse the regulation from art. $2^{l}$ Law no. 206/2004 and some examples of situations when deviations can became offences. To complete this picture frame in conclusions we propose some changes of the current legislations.
\end{abstract}

KEYWORDS: offence, rules, law, scientific research

\section{Introduction}

Regarding the analyses of the situations when the rules of good conduct in scientific activity can constitute crimes, we must stop, at first, and define the crime, to notice then the differences between the deviations from the norms of good conduct in scientific activity regulated by law and offenses.

In a broad sense, the crime is defined as being: any deed of a man prohibited by law (Streteanu \& Niţu, 2014, p. 251) and legally sanctioned by punishment.

In the current legislation, according to art. 15 par. (1) Criminal code, the crime is: the deed provided by the criminal law, committed with guilt, unjustified and imputable to the person who committed it.

The offenders are obliged to bear the consequences of the unlawful deeds and to be punished according to the criminal law in force at the date of the crime.

In particular, the person who committed the deed can be held accountable only if it fulfils all the essential features of offences from the definition regulated by art. 15 par. (1) Criminal code.

The first essential feature it is based on the condition that the deed must be provided by the criminal law, forming in this case the 
legal framework. In doctrine it is also known under the name of typicity (Antoniu, 1997, pp. 15-17).

Also, the act to be considered typical must correspond to the abstract model described by the legislator (Mitrache \& Mitrache, 2016, p. 136).

The second essential feature of the crime concerns committing the deed with guilt (Antoniu, 2003, pp. 9-12).

In the case of these feature we have in mind the perpetrator's mental attitude towards the deed, which also determines the forms of guilt. Thus the guilt is presented in three forms: intention, guilt and overcome intention. What offers the differentiation between these forms is the intelligential factor of predicting the deed (Mitrache \& Mitrache, 2016, p. 138) which the author has, meaning to foresee the deed which is going to constitute the actual offense.

The third essential feature of crime refers to the unjustified nature of the deed, which is also known in the criminal doctrine under the concept of anti-juridical (Streteanu \& Niţu, 2014, pp. 255-256; Mitrache \& Mitrache, 2016, pp. 142-143).

In fact, although the deed fulfils all the conditions of the incriminating norm, falling within a typical act, that is, provided by the criminal law, if the law permits the act under certain conditions, then we have to deal with the situation in which the deed is not a crime. These conditions are regulated by art. 19-22 of the Criminal code, under the name of justifying causes (Udroiu, 2014, p. 25; Mitrache \& Mitrache, 2016, pp. 142-143).

The deed may present the justified nature as long as it is not incidental: the selfdefence, the state of necessity, the exercise of a right or the fulfilment of an obligation, and the consent of the injured party.

The fourth essential feature of the crime is that the act is imputable to the person who committed it, both physically and mentally. More specifically, the perpetrator's will must not be constrained (Mitrache, Mitrache, 2016, p. 143) in any way.
The criminal responsibility of the deed exists only if one of the causes of criminal responsibility provided by art. 24 of Criminal code - physical constraint, art. 25 of Criminal code - moral constraint, art. 26 of Criminal code - unreachable excess, art. 27 of Criminal code - minority of the perpetrator, art. 28 of Criminal code - irresponsibility, art. 29 of Criminal code - intoxication, art. 30 of Criminal code - error, art. 31 of Criminal code - fortuity, is not incidental.

Under this text of law from above, it is necessary to fulfil the four essential features of a deed to become a crime.

We underline the fact that the situations when the deviations from the rules of good conduct in the scientific activity are or not a crime will be analysed from the perspective of fulfilling or not the traits essentials of crime.

\section{Rules of Good Conduct in Scientific Activity}

Under Law no. 204/2001 the norms of good conduct in the scientific activity are not defined, but are regulated in art. $2^{1}$ the deviations from the rules of good conduct. All these norms are complemented by the Code of Ethics, provided by Law no. 319/2003 regarding the Statute of Research and Development Staff, as well as in the codes of ethics by field, elaborated according to art. 7, let. b) by the National Ethics Council. Among the tasks of the Council are also the development of codes of ethics in scientific fields, which it proposes for approval to the state authority for research and development.

In concrete, an example in this regard, is the Code of Ethics in the scientific research at the University of Petrosani, which analyse good conduct in scientific research through four rules: law observance, guaranteeing freedom in science, in scientific research and in education; respecting the principles of good scientific practice and assuming responsibilities (Universitatea din Petroşani, 2015, p. 1). 


\section{Deviations from the Rules of Good Conduct in Scientific Activity}

According to art. $2^{1}$ par. (1) of Law no. 206/2004: deviations from the rules of good conduct provided in art. 2 , let. a), are those relating to scientific activity, in so far as they do not constitute crimes, in particular do not fulfil all four essential features of the crime according to the criminal law, are presented in three forms.

According to art. $2^{1}$ par. (1) let. a), the first form of deviation refers to the making of results or data (Academia Română, 2016, p. 404) and presenting them as experimental data.

According to the current language, the term "experiment" has the meaning of a scientific research process, which consists in deliberately provoking phenomena for studying them (Bodoașcă \& Murgu, 2016, p. 83). Under this consideration, we argue that this case of deviation is based on data that are presented as experimental, even if they did not pasted through the filter of provoked observation so they cannot be presented as such.

The regulation of art. $2^{1}$, par. (1) let. a) may constitute an offense unless it meets all four essential features of the crime presented in the introduction section.

An another form of deviation regulated by art. $2^{1}$ par. (1) let. a) of Law 206/2004 considers the production of results or data and their presentation as data obtained through computer numerical calculations or simulations, or as data or results obtained by analytical calculations or deductive reasoning.

We mention that the term „calculations” according to DEX, is assemblies of mathematical operations made with a particular purpose to find the values of some sizes or expressions, and since these values are not found, we cannot talk about data obtained by computation.

The simulations make something unrealistic to be true, and moreover the numerical simulations start right from the beginning with intentionally misleading, introduced data most of the times, especially regarding deviations from art. $2^{1}$ par. (1) lit. a) of Law no. 206/2004.

All variants through which the deviation can be made concern the making of data or results itself, which means processing in such a way as to obtain the desired results without realizing anything concrete in this respect.

For example, presenting data as the result of complex mathematical computations at a scientific symposium is a deviation from the rules of good conduct in scientific activity to the extent that they are produced by the person who presents them as being true. In this case, the person can be held accountable for the crime of deception (art. 244 C. pen.), because he has presented a false act as a true one. More, the goal must be to obtain for himself or for another an unjust patrimonial benefit and cause damage, so that the deed to be classified as a crime of deception.

A second form of deviation is regulated in art. $2^{1}$ par. (1) lit. b) Law no. 206/2004 that includes the deviations from the standards of good conduct in scientific activity through falsifying data.

According to DEX, the term "falsification" represents the action of making or manufacturing a thing similar to another, with the purpose of deceiving (Academia Română, p. 413), being synonymous with the term counterfeiting.

It should be noticed that are covered more categories of data in art. $2^{1}$ par. (1) lit. b) Law no. 206/2004, so we have: experimental data, data obtained through calculations or numeric simulations on the computer or date or results obtained through analytical calculations or deductive reasoning.

At first glance, what distinguishes the deviations presented in lit. a) compared to those from lit. b) of art. $2^{1}$ par. (1) Law no. 206/2004 are the very actions through they can be accomplished. Thereby, "manufacturing" represents the action of 
processing a material or semi-fabric to obtain an object (Academia Română, p. 239), in the case of deviations, the object is represented by the results or data presented. The action regulated by law through lit. b) is defined in DEX with the help of the terms manufacturing action, which makes us conclude that actually, the regulation from lit. a) is only completing the regulation from lit. b). We emphasize that for these reasons, we suggest to the legislator, de lege ferenda, to merge the regulations from art. $2^{1}$ par. (1) lit. a) and lit. b) Law no. 206/2004 into one.

Deviations provided in art. $2^{1}$ par. (1) lit. b) Law no. 206/2004 may constitute offenses if they fulfill the essential features of the offenses.

The third form of deviation is regulated by art. $2^{1}$ par. (1) lit. c) Law no. 206/2004, according to which: deliberately difficulty, the prevention or sabotaging other people's research and development activity is a form of deviation from the rules of good conduct in scientific activity.

In certain situations in which the actions thorough these violations are committed constitute criminal offenses according to the criminal law, the form of guilt will be direct intention, because the foresee exists, it is intended to achieve the result itself and the acceptance is an integral part of the process from its incipient state.

Keeping up with the regulations you've got above, we have different ways through deviation or crime can be realized. Thus, the legislator took into account the unjustified blocking of the researchdevelopment access spaces, through actions like: breakdown, destruction or manipulation of experimental device, of equipment, of documents, of computer programs, of data in electronic format, but also on organic or inorganic substances or live material necessary to other persons to run, to realize and to finalize the activity of research and development.

On the base of these text, multiple actions by which the deviation or offense can be committed, as the case may be, reflects the firm position of the legislator over these violations.

The purpose of these vast regulation from art. $2^{1}$ par. (1) lit. c) Law no. 206/2004 is to cover any area of research and development in all the fields.

The sanctions regulated by art. $11^{1}$ lit. a) - f) Law no. 206/2004 are trifling regarding to the punishments provided by the Criminal Code, because the act itself differs according to severity and outcome. We propose, de lege ferenda, an analysis of these sanctions and a reorientation towards a greater difficulty, allowing a rigor regarding the violation of norms of good conduct in scientific activity.

\section{Conclusions}

The norms of good conduct in scientific activity are complemented by Law no. 319/2003 regarding the Status of research and development staff, in particular through the rights provided by art. 23 , which complete, through freedom of access to all sources of information and documentation and not only these one, the rights and freedoms of research and development staff and of academic staff to.

The ethics codes in scientific fields are those that realize all the necessary rules of good conduct.

In our opinion, current regulations in this area should be complemented, first of all with severe penalties, even if we only talk about deviations, in this area of scientific research the slanderous results may include a whole domain with practical applicability to mankind itself. For example, if we consider a falsification of experimental data in the pharmaceutical field, which can extend to experiments made on volunteers, human beings, due to intentionally altered data. In this case, however, the barrier of deviation is passed, but this is due to the lack of sufficient internal measures taken by the institution within the deviation is committed. 
Another conclusive example is the case of Jan Hendrick Schön, who has received many awards and it was considered "breakthroughs of the year" in 2001 by Science Magazine.

Eventually he admitted that the data was incorrect in many of his works and he admitted falsifying data from the desire to show more convincing evidence. As a result, many of his articles were withdrawn and the University of Konstanz withdrew his doctor's title due to "unreasonable conduct" (Stan, 2007-2013, pp. 17-19).

On the other side, good conduct in scientific research should include besides: compliance of the law; guaranteeing freedom in science, scientific research and education; respecting the principles of good scientific practice and assuming responsibilities
(Stan, 2007-2013, p. 4) even a better awareness of what's happening in the moment when the results or data are altered in any way. And this problem can only be solved by amending and completing the Law no. 206/2004 with a clear regulation regarding the rules of good conduct in scientific activity, but also a legislate for deviations from these norms more specifically formulated.

Finally, the line is thin in terms of switching from deviation to offense, it is all based on the four essential features of the offense, which marks a barrier between sanctions and punishments. Especially from these reason, de lege ferenda, we propose a detailed regulation for the definition of "deviation" in the legal field, to eliminate any form of confusion that exists today.

\section{REFERENCES}

Academia Română. (2016). Dicționarul explicativ al limbii Române (DEX), Bucureşti; Univers Enciclopedic, 404.

Antoniu, G. (1997). Tipicitate și antijuridicitate. Revista de Drept Penal, nr. 4, 15-17.

Antoniu, G. (2003). Vinovăția în perspectiva reformei penale și a aderării la Uniunea Europeană, Revista de Drept Penal, nr. 2, 9-12.

Bodoașcă, T. \& Murgu, A. (2016). Opinii privind semnificaţia juridică a plagiatului, Revista Română de Dreptul Proprietății Intelectuale, $n r .4,83$.

Law no. 206 from 27 May 2004 on good conduct in scientific research, technological development and innovation modified and completed through Law no. 398/2006 published in Monitorul Oficial, Part I no. 892 din 02/11/2006, and through Ordonanţa Guvernului no. 28/2011 published in Monitorul Oficial, Part I, no. 628 from 02/09/2011.

Law no. 319 from 8 July 2003 regarding the status of research and development staff, Published in: Monitorul Oficial, Part I, no. 530 from 23 July 2003.

Mitrache, C-tin. \& Mitrache, C. (2016). Drept penal român, Partea generală, ediţia a doua, revizuită şi adăugită, Bucureşti: Universul juridic, 136-143.

Stan. R. (2007-2013). Ethics in research. Good conduct in research and development. Postdoctoral program for advanced nanomaterial research, Bucharest: Politehnica University, 17-19.

Streteanu, F. \& Nițu, D. (2014). Drept penal. Partea generală. Volumul I, Bucureşti: Universul juridic, 251-256.

Udroiu, M. (2014). Fișe de drept penal. Partea generală. Noul Cod penal, Bucureşti. Universul juridic, 25.

Universitatea din Petroşani. (2015). Codul de etică în cercetarea ştiinţifică în Universitatea din Petroşani, Petroşani: Author, 1. 